\title{
Temperature Sensitivity and Efficacy of Wheat streak mosaic virus Resistance Derived from C0960293 Wheat
}

D. L. Seifers, Professor, and T. J. Martin, Professor, Kansas State University Agricultural Research Center-Hays, Hays 67601; T. L. Harvey, Professor, Department of Entomology, Kansas State University, Manhattan 66506; S. Haber, Cereal Research Center, Agriculture \& Agri-Food Canada, Winnipeg, Canada; and S. D. Haley, Soil and Crop Science Department, Colorado State University, Fort Collins 80523

\begin{abstract}
Seifers, D. L., Martin, T. J., Harvey, T. L., Haber, S., and Haley, S. D. 2006. Temperature sensitivity and efficacy of Wheat streak mosaic virus resistance derived from CO960293 wheat. Plant Dis. 90:623-628.

Wheat yields often are limited by infection by Wheat streak mosaic virus (WSMV). Host plant resistance to WSMV can reduce losses. This study was conducted to characterize a new source of temperature-sensitive resistance found in CO960293 wheat. The source of the temperaturesensitive resistance in CO960293 is unknown. Parental and other wheat lines were tested for WSMV resistance using $51 \mathrm{WSMV}$ isolates under different temperatures to determine the stability of the resistance, and yield trials were conducted in the field for 3 years. All parental wheat lines became infected by WSMV at all temperatures and were infective in back assay to 'Tomahawk' wheat. No WSMV isolate defeated the resistance of $\mathrm{CO} 960293$ at $18^{\circ} \mathrm{C}$. Yield of CO960293 in field trials was reduced in only 1 of 3 years. Our data demonstrate that this wheat line can be a valuable source of resistance to WSMV in wheat programs, particularly in areas where temperatures are cool following planting in the fall.
\end{abstract}

Infection of wheat by Wheat streak mosaic virus (WSMV), vectored by the wheat curl mite (WCM) Aceria tosichella Keifer (15), causes wheat streak mosaic, a serious disease of wheat in Kansas causing losses as high as $13 \%$ reduction in yield of the wheat crop $(5,14,18)$.

High levels of WSMV resistance are not available in commercial cultivars. Lower levels of resistance are available, but these cultivars suffer significant yield losses under high WSMV pressure (12). The KS96HW10-3 germ plasm derived from Agropyron intermedium has been shown to have a high level of resistance under field conditions (13). The resistance from $A$. intermedium has been shown to be tightly linked to the gene identified as wsml, and its presence can be verified using the $\mathrm{J} 15$ (SCAR) DNA marker (17). This source was demonstrated to be temperaturesensitive; however, under field conditions, this resistance still was effective in preventing losses to WSMV infection (13). To date, this is the only temperature-sensitive

Corresponding author: D. L. Seifers

E-mail: dseifers@ksu.edu

Contribution No. 05-292-J from the Kansas Agricultural Experiment Station, Manhattan, Kansas 66506. Research was supported in part by a grant from the Kansas Wheat Commission.

Accepted for publication 21 December 2005.

DOI: 10.1094/PD-90-0623

(C) 2006 The American Phytopathological Society source of resistance to WSMV that has been identified.

In 1999, wheat from the Hard Winter Wheat Regional Germplasm Observation Nursery was tested at Hays, KS under natural infestation with WCM viruliferous for WSMV in a WSMV resistance screening nursery (8). All plants of wheat line CO960293 (PI222668/TAM 107// CO850034 pedigree) remained symptomless in this field test. The symptomless plants tested negative in enzyme-linked immunosorbent assay (ELISA) against antisera to WSMV and the High Plains virus. A homozygous single-plant selection made from CO960293 has been released as germ plasm CO960293 (3).

The objective of this work was to characterize the type and effectiveness of the WSMV resistance of CO960293 and other wheat germ plasm under greenhouse, growth-chamber, and field conditions.

\section{MATERIALS AND METHODS}

Sources and maintenance of WSMV isolates. Fifty-one WSMV isolates were used in these studies (Table 1). The susceptible wheat cv. Tomahawk was mechanically inoculated on the first leaf using the finger-rub technique (11) and held in a growth chamber at 20 to $22^{\circ} \mathrm{C}$ for 2 weeks. The symptomatic plant tissue then was frozen at $-80^{\circ} \mathrm{C}$ until needed. Inoculations in all experiments were done using thawed portions of such frozen tissue. Inoculum was prepared by grinding infected tissue in a mortar and pestle at a 1:10 (wt/vol) dilution in $0.02 \mathrm{M}$ potassium phosphate buffer
(pH 7). The homogenate was filtered through cheesecloth, and $1 \mathrm{~g}$ of abrasive (Crystolon flour B, 600 mesh; Norton Co., Worcester, MA) was added for $100 \mathrm{ml}$ of inoculum. This method of inoculum preparation and inoculation used throughout this investigation has been described previously (11).

Infectivity assays. Tomahawk wheat was mechanically inoculated as described above at the single-leaf stage with 1:5 (wt/vol) extracts prepared from different wheat lines. Inoculated plants were held in a greenhouse under natural lighting and rated for numbers of symptomatic plants at 14 days post inoculation (DPI).

Indirect ELISA. Leaf tissue was ground 1:30 (wt/vol) in $0.05 \mathrm{M}$ carbonate buffer, pH 9.6 (1). Extracts $(200 \mu \mathrm{l})$ were placed in wells of ELISA plates (Immulon 1; Dynatech Laboratories, Inc., Chantilly, VA) for $1 \mathrm{~h}$ at $37^{\circ} \mathrm{C}$. Following rinsing, the wells were incubated for $1 \mathrm{~h}$ at $37^{\circ} \mathrm{C}$ with a WSMV antivirus antibody (12) dilution of $5 \mu \mathrm{g} / \mathrm{ml}$ in blocking buffer (5\% nonfat dry milk, $0.01 \%$ antifoam $\mathrm{A}$, and $0.02 \%$ sodium azide in phosphate-buffered saline, $\mathrm{pH}$ 7.4). The plates then were rinsed and blocked for $1 \mathrm{~h}$ at $37^{\circ} \mathrm{C}$. Then, $200 \mu \mathrm{l}$ of anti-rabbit antibody/alkaline phosphatase conjugate (Southern Biotechnology Associates, Birmingham, AL) in blocking buffer $(1: 3,000 \mathrm{vol} / \mathrm{vol})$ was added per well. The plates were held at $37^{\circ} \mathrm{C}$ for $1 \mathrm{~h}$. The plates then were rinsed, and $200 \mu$ of substrate (p-nitrophenyl phosphate, 0.714 $\mathrm{mg} / \mathrm{ml}$ ) in substrate buffer (1) was added to each well. The plates then were held at room temperature $\left(20\right.$ to $22^{\circ} \mathrm{C}$ ) for $30 \mathrm{~min}$. Absorbance was measured at $405 \mathrm{~nm}$ using a Titertek Multiscan plate reader (Flow Laboratories, Inc., McLean, VA). Absorbance values were considered positive if they were twice those of the equivalent mock-inoculated control.

WSMV testing of wheat lines. Seed of wheat lines CO960255, CO960223, CO960293, CO960315, CI6501, KS96H103 , plant introduction (PI)222651, PI222655, PI222661, PI222666, PI222668, PI222671, PI222679, PI222680, PI222681, and PI222682 were planted into 30-by-50-cm soil-filled metal flats at 10 seed per row for each entry with eight rows per flat for a total of four flats (two for each temperature). Plants were mechanically inoculated as described above with WSMV isolate 
Sidney 81 at the single-leaf stage. One set of plants was held at $18^{\circ} \mathrm{C}$ in a growth chamber for 14 days with $8 \mathrm{~h}$ of illumination $\left(250 \mu \mathrm{E} \mathrm{sec}-1 \mathrm{~m}^{-2}\right)$ per day and one set of plants was held for 14 days at $24^{\circ} \mathrm{C}$ in a growth chamber with the same light conditions. Symptom expression of both sets was recorded at 14 DPI. The experiment was conducted twice. All plantings in these and other experiments conducted in the course of this investigation used a Harney clay loam (fine montmorillonitic, mesic Typic Argiustoll) soil. Lines PI222651 to PI222682 were tested to determine whether they might have resistance to WSMV because preliminary tests showed that the parental lines PI222668, TAM 107, and CO850034 were susceptible to infection by WSMV (D. L. Seifers, unpublished).
WSMV infectivity testing of C0960293 and parental wheat lines. Wheat lines CO960293, CO850034, PI222668, and TAM107 were planted into 30-by-50-cm soil-filled (soil type as described above) metal flats at 10 seed per row for each entry so that each flat contained one row for each wheat line. Two sets of this planting were done so that plants were available for the 18 and $24^{\circ} \mathrm{C}$ temperature treatments. The plants were held at $18^{\circ} \mathrm{C}$ until they were at the singleleaf stage and then were mechanically inoculated as described above on the first leaf with a $1: 10 \mathrm{wt} / \mathrm{vol}$ dilution of the Sidney 81 isolate of WSMV. The plants then were placed immediately in growth chambers at either the 18 or $24^{\circ} \mathrm{C}$ temperature treatment. A randomized complete block

Table 1. Wheat streak mosaic virus (WSMV) isolate designation, origin, isolation host, and year of isolation

\begin{tabular}{|c|c|c|c|}
\hline WSMV isolate & Location of origin & Isolation host & Year isolated \\
\hline BT95 & Kansas & Wheat & 1995 \\
\hline CK93 & Kansas & Wheat & 1993 \\
\hline CL93 & Kansas & Wheat & 1993 \\
\hline CM93 & Kansas & Wheat & 1993 \\
\hline $\mathrm{CO} 85$ & Kansas & Wheat & 1985 \\
\hline CO87 & Colorado & Wheat & 1987 \\
\hline El Batán 3 & Mexico & Wheat & 1996 \\
\hline EW95 & Kansas & Wheat & 1995 \\
\hline FO93 & Kansas & Wheat & 1993 \\
\hline GH95 & Kansas & Wheat & 1995 \\
\hline GO93 & Kansas & Wheat & 1993 \\
\hline GY93 & Kansas & Wheat & 1993 \\
\hline H81 & Kansas & Wheat & 1981 \\
\hline H88 & Kansas & Wheat & 1988 \\
\hline H94PM & Kansas & Wheat & 1994 \\
\hline $\mathrm{H} 94 \mathrm{~S}$ & Kansas & Wheat & 1994 \\
\hline H94USDA & Kansas & Wheat & 1994 \\
\hline H95LB & Kansas & Wheat & 1995 \\
\hline $\mathrm{H} 95 \mathrm{~S}$ & Kansas & Wheat & 1995 \\
\hline $\mathrm{H} 98$ & Kansas & Wheat & 1998 \\
\hline HM93 & Kansas & Wheat & 1993 \\
\hline HV91 & Kansas & Wheat & 1991 \\
\hline ID96 & Idaho & Wheat & 1996 \\
\hline ID99 & Idaho & Maize & 1999 \\
\hline $\mathrm{IHC}$ & Canada & Wheat & 1989 \\
\hline KM93 & Kansas & Wheat & 1993 \\
\hline KY00 & Kentucky & Wheat & 2000 \\
\hline KY0083SV & Kentucky & Wheat & 2000 \\
\hline LC95 & Kansas & Wheat & 1995 \\
\hline LG92 & Kansas & Wheat & 1992 \\
\hline MO00 & Missouri & Wheat & 2000 \\
\hline MO99 & Missouri & Wheat & 1999 \\
\hline MON96 & Montana & Wheat & 1996 \\
\hline ND & North Dakota & Wheat & 1969 \\
\hline NE96 & Nebraska & Wheat & 1996 \\
\hline OK98 & Oklahoma & Wheat & 1998 \\
\hline OSU & Unknown & Unknown & Unknown \\
\hline PL95 & Kansas & Wheat & 1995 \\
\hline PN95 & Kansas & Wheat & 1995 \\
\hline PV106 & Ohio & Maize & 1964 \\
\hline PV106JM & Ohio & Maize & 1964 \\
\hline PV57 & Kansas & Wheat & 1932 \\
\hline PV91 & Kansas & Wheat & 1949 \\
\hline RO95 & Kansas & Wheat & 1995 \\
\hline SD96 & South Dakota & Wheat & 1996 \\
\hline Sidney 81 & Nebraska & Wheat & 1981 \\
\hline TK1 & Turkey & Wheat & 1999 \\
\hline TK2 & Turkey & Wheat & 1999 \\
\hline TX96 & Texas & Wheat & 1996 \\
\hline WA99 & Washington & Maize & 1999 \\
\hline WO93 & Ohio & Maize & 1993 \\
\hline
\end{tabular}

design was used with the location of wheat lines within flats randomized, as were the positions of the flats within the growth chambers. At 21 DPI, all symptomatic tissues of the third leaves were bulked (within a wheat line) and ground in $0.02 \mathrm{M}$ $\mathrm{KPO}_{4}, \mathrm{pH} 7$, buffer at a 1:25 wt/vol dilution. From this preparation, serial dilutions of $1: 50,1: 100,1: 200,1: 400,1: 800$, $1: 1,600$, and 1:3,200 were prepared. The extracts were used to inoculate Tomahawk wheat plants ( 7 to 10 plants per dilution at the single-leaf stage) as described above. The inoculated Tomahawk infectivity assay plants were held in a greenhouse under natural lighting (temperatures ranged from 19 to $28^{\circ} \mathrm{C}$ ) prior to determining the number of symptomatic plants at 14 DPI. The experiment was conducted three times. Infection percentage data were transformed with the arcsine transformation before analysis of variance because the range of percentages among treatments was greater than 40 (6); untransformed data will be presented. The analysis of variance (ANOVA) for the data was conducted using SAS (version 8; SAS Institute, Cary, NC) and significant treatment effects were determined using the least significance difference (LSD) test at $P=$ 0.05 .

Wsm1 gene probe. Healthy wheat leaves of CO960293, CO960315, CO960255, CI15092, KS96HW10-3, TAM 107 , and the Canadian spring wheat cvs. AC Elsa and AC Superb were tested for the presence of the J15 (SCAR) DNA marker, which has been shown to be tightly linked to the presence of the resistance gene, wsml, derived from Thinopyrum intermedium (17).

DNA extraction. Wheat leaf pieces (approximately 3 by $1 \mathrm{~cm}$ each) were placed in individual 15-ml tubes and lyophilized overnight. The tissue in each tube was pulverized by vigorous abrasion with acidwashed sand ( $2 \mathrm{ml}$ of sand per tube, $5 \mathrm{~min}$ of agitation on a commercial paint shaker), then extracted with $6 \mathrm{ml}$ of DNA extraction buffer $(0.1 \mathrm{M}$ Tris- $\mathrm{HCl}, \mathrm{pH} 8.7 ; 0.05$ $\mathrm{M}$ EDTA, pH 8.0; $1.5 \mathrm{M} \mathrm{NaCl}$; and $1 \%$ cetyltrimethylammonium bromide) to which $30 \mu \mathrm{l}$ of proteinase $\mathrm{K}(10 \mathrm{mg} / \mathrm{ml}$ in Tris-EDTA buffer $[10 \mathrm{mM}$ Tris- $\mathrm{HCl}, \mathrm{pH}$ 7.6, and $1 \mathrm{mM}$ EDTA] $\mathrm{pH}$ 7.6) and $660 \mu \mathrm{l}$ of $20 \%(\mathrm{wt} / \mathrm{vol})$ sodium dodecyl sulfate were added $\left(2 \mathrm{~h}\right.$ of incubation at $65^{\circ} \mathrm{C}$ in a water bath), followed by addition in a fume hood of $6 \mathrm{ml}$ of chloroform/isoamyl alcohol (24:1). After slow shaking for 30 min, the tubes were centrifuged at $5,000 \times$ $g$ for $10 \mathrm{~min}$. The supernatant (approximately $3 \mathrm{ml}$ ) from each tube was removed to a fresh tube and $3 \mathrm{ml}$ of ice-cold isopropanol was added. The DNA which precipitated at the interface between the two phases was removed $(1 \mathrm{ml})$ to a microcentrifuge tube, then pelleted by centrifugation at $15,000 \times g$ for $20 \mathrm{~min}$. After washing with $70 \%$ (vol/vol) ethanol, DNA 
pellets were left in $70 \%$ ethanol overnight at $-20^{\circ} \mathrm{C}$, centrifuged at $15,000 \times g$ for 20 min, and the ethanol decanted. The pellets were allowed to air dry; then, each pellet was dissolved in $250 \mu \mathrm{l}$ of autoclaved, deionized water.

Amplification of marker DNA by polymerase chain reaction. Amplifications of the 241-bp J15 marker DNA sequence were carried out using a polymerase chain reaction (PCR) DNA amplification kit (cat. no. N808-0130; Perkin Elmer-Roche Diagnostics, Nutley, NJ) and the custom primers left primer $\left(5^{\prime}-3^{\prime}\right)$ GTA GCA GGG GAA GCT GAA GA and right primer $\left(5^{\prime}-3^{\prime}\right)$ CCG AGC TCA CAC GCT AAT TT $(10 / \mu \mathrm{l})$. From the kit, the following reagents were added to a microcentrifuge tube: $32 \mu \mathrm{l}$ of deionized water, $7.5 \mu \mathrm{l}$ of reverse-transcription PCR buffer, $5 \mu \mathrm{l}$ of $\mathrm{MgCl}_{2}$, and $5 \mu \mathrm{l}$ of $10 \times$ dNTPs. To this mixture, $2.5 \mu \mathrm{l}$ of each of the left and right primer DNA, $1 \mu \mathrm{l}$ of the target DNA sample, and $0.75 \mu$ l of Taq DNA polymerase (5 units $/ \mu \mathrm{l})$ were added. After mixing the

Table 2. Numbers of symptomatic wheat plants from different lines following mechanical inoculation with Wheat streak mosaic virus (WSMV) and being held at 18 or $24^{\circ} \mathrm{C}$ for 2 weeks following inoculation

\begin{tabular}{lcc}
\hline & \multicolumn{2}{c}{ Temperature $\left({ }^{\mathbf{o}} \mathbf{C}\right)^{\mathbf{z}}$} \\
\cline { 2 - 3 } Wheat line & $\mathbf{1 8}$ & $\mathbf{2 4}$ \\
\hline CO960255 & $8 / 8$ & $8 / 8$ \\
CO960293 & $0 / 10$ & $9 / 10$ \\
CO960315 & $10 / 10$ & $10 / 10$ \\
CO960223 & $15 / 16$ & $16 / 16$ \\
CI6501 & $15 / 15$ & $12 / 12$ \\
KS96HW10-3 & $0 / 10$ & $9 / 9$ \\
PI222651 & $4 / 4$ & NT \\
PI222655 & $7 / 7$ & NT \\
PI222661 & $6 / 6$ & NT \\
PI222666 & $9 / 9$ & NT \\
PI222668 & $14 / 14$ & NT \\
PI222671 & $10 / 10$ & NT \\
PI222679 & $4 / 4$ & NT \\
PI222680 & $5 / 5$ & NT \\
PI222681 & $5 / 5$ & NT \\
PI222682 & $4 / 4$ & NT \\
\hline
\end{tabular}

${ }^{\mathrm{z}}$ Numerator represents the total number of symptomatic plants and the denominator the total number of plants mechanically inoculated with WSMV in two experiments; NT $=$ not tested. reagents by gently flicking each microcentrifuge tube, thermal cycling was carried out in a PTC 100-MJ thermocycler (MJ Research, Watertown, MA) for $3 \mathrm{~min}$ at $94^{\circ} \mathrm{C}$, followed by 34 cycles of $1 \mathrm{~min}$ at $94^{\circ} \mathrm{C}, 1 \mathrm{~min}$ at $60^{\circ} \mathrm{C}$, and $2 \mathrm{~min}$. at $72^{\circ} \mathrm{C}$; a 10 -min period of annealing at $72^{\circ} \mathrm{C}$; and concluding with cooling overnight at $4^{\circ} \mathrm{C}$.

PCR DNA products were analyzed in a $1.5 \%$ agarose gel containing ethidium bromide (2). The PCR product $(10 \mu \mathrm{l})$ was mixed with $1.5 \mu \mathrm{l}$ of PCR Loading Buffer (Perkin Elmer-Roche Diagnostics) and loaded into the gel, and electrophoresis was conducted for $2 \mathrm{~h}$ at $40 \mathrm{~V}$. The presence or absence of the J15 SCAR DNA marker was noted compared with the 241bp single band produced by the PCR reaction with DNA extracted from the positive control wheat lines CI15092 and KS96H10-3.

Temperature and WSMV isolate interactions for $\mathbf{C O 9 6 0 2 9 3}$ resistance. Seed of CO960293 wheat was sieved to uniform size and planted in 30-by-50-cm soil-filled (11 kg of soil) metal flats, each with 22 rows (12 cm long). Six flats were used in each of three runs of the experiment (three flats for the $18^{\circ} \mathrm{C}$ treatment and three flats for the $24^{\circ} \mathrm{C}$ treatment). When the plants were at the single-leaf stage, each row was thinned to 10 plants of uniform size. The plants in a row then were mechanically inoculated (as described above) with one of the 51 WSMV isolates. One row in each flat was mock inoculated with buffer and abrasive as the healthy control. A randomized complete block design was used and the location of WSMV isolates and the healthy wheat control within flats was randomized, as were the locations of the flats in the growth chambers. The outer two rows of each flat were planted with wheat that was not inoculated so that all inoculated plants were surrounded by wheat on each side. Plants were held in a growth chamber at either 18 or $24^{\circ} \mathrm{C}$. Plants were rated on a daily basis for first-symptom expression and for severity (whole plant and averaged for all plants in a row) at 21 DPI according to the following symptom scale: $1=$ no symptoms, $2=$ faint mosaic, $3=$ moderate mosaic, $4=$ severe mosaic, and $5=$ severe mosaic with yellowing of leaves. At 21 DPI, the plants within a row were cut at the soil surface, bulked for a given WSMV isolate or healthy control, and placed in labeled paper bags, and the plant tissue was dried to a constant weight.

ANOVAs (first-symptom expression, symptom severity, and dry weight) were performed using the general linear models procedure of SAS. In the analysis, the uninoculated, symptomless controls and plants inoculated with the El Batán 3 WSMV isolate were assigned a 15-day value to facilitate data analysis. Treatment means were separated using the Tukey's Studentized Range test.

Confirmation of infectivity of selected WSMV isolates on C0960293 grown at 18 and $24^{\circ} \mathrm{C}$. The WSMV isolates LG92, CM93, El Batán 3, ND, WO93, and IHC were used to mechanically inoculate CO960293 and Tomahawk wheat. Wheat was planted in two 30-by-50-cm soil-filled metal flats each flat with six rows. Each row of plants was inoculated (as described above) at the single-leaf stage and then one of the two flats was placed at $18^{\circ} \mathrm{C}$ and the other at $24^{\circ} \mathrm{C}$. After 2 weeks at $24^{\circ} \mathrm{C}$, the third leaf was harvested from each plant and bulked within a row inoculated with a given WSMV isolate and a 1:5 wt/vol dilution of extract was prepared (as described above). The extract from plants infected with each virus isolate was used to inoculate a separate row of Tomahawk wheat seedlings (10 plants) planted 7 days previously. After 3 weeks at $18^{\circ} \mathrm{C}$, the third leaves of plants inoculated with a respective WSMV isolate were bulked and used to make a $1: 5 \mathrm{wt} / \mathrm{vol}$ dilution of extract. This extract was used to mechanically inoculate Tomahawk wheat seedlings planted 1 week previously, as described for the $24^{\circ} \mathrm{C}$ treatment. The experiment was conducted three times. The WSMV isolates were chosen from among the 51 isolates because of varied reaction for CO960293 wheat observed in the 18 and $24^{\circ} \mathrm{C}$ isolate interaction study.

Yield trials. Yield trials were conducted to compare the effectiveness of the resistance of CO960293 to that of KS96HW103 that carries resistance from A. intermedium (13). Several wheat cultivars with

Table 3. Percentages of 'Tomahawk' wheat plants infected by Wheat streak mosaic virus (WSMV) following mechanical inoculation with different dilutions of plant extract prepared from plants of different wheat lines grown at either 18 or $24^{\circ} \mathrm{C}^{\mathrm{z}}$

\begin{tabular}{|c|c|c|c|c|c|c|c|}
\hline \multirow[b]{2}{*}{ Wheat, temperature $\left({ }^{\circ} \mathrm{C}\right)$} & \multicolumn{7}{|c|}{ Reciprocal of plant dilution } \\
\hline & 50 & 100 & 200 & 400 & 800 & 1,600 & 3,200 \\
\hline CO850034, 18 & $100 \mathrm{~A}$ & 83 A-D & $56 \mathrm{~F}-\mathrm{J}$ & $38 \mathrm{I}-\mathrm{M}$ & $13 \mathrm{~L}-\mathrm{P}$ & $60 \mathrm{Q}$ & $0 \mathrm{Q}$ \\
\hline CO850034, 24 & $100 \mathrm{~A}$ & $100 \mathrm{~A}$ & $97 \mathrm{~B}$ & $93 \mathrm{~A}-\mathrm{C}$ & 83 A-D & $59 \mathrm{E}-\mathrm{I}$ & $42 \mathrm{H}-\mathrm{M}$ \\
\hline CO960293, 18 & $0 \mathrm{Q}$ & $0 \mathrm{Q}$ & $0 \mathrm{Q}$ & $0 \mathrm{Q}$ & $0 \mathrm{Q}$ & $0 \mathrm{Q}$ & $0 \mathrm{Q}$ \\
\hline CO960293, 24 & $100 \mathrm{~A}$ & $100 \mathrm{~A}$ & $93 \mathrm{~A}-\mathrm{C}$ & $81 \mathrm{~B}-\mathrm{D}$ & $60 \mathrm{E}-\mathrm{I}$ & $23 \mathrm{~K}-\mathrm{O}$ & $7 \mathrm{~N}-\mathrm{Q}$ \\
\hline PI222668, 18 & $100 \mathrm{~A}$ & $100 \mathrm{~A}$ & $100 \mathrm{~A}$ & 87 A-D & 47 G-K & $23 \mathrm{~K}-\mathrm{O}$ & $7 \mathrm{~N}-\mathrm{Q}$ \\
\hline PI222668, 24 & $100 \mathrm{~A}$ & $100 \mathrm{~A}$ & $100 \mathrm{~A}$ & $87 \mathrm{~A}-\mathrm{C}$ & 73 B-F & $42 \mathrm{H}-\mathrm{M}$ & $20 \mathrm{~L}-\mathrm{P}$ \\
\hline TAM 107,18 & $100 \mathrm{~A}$ & $63 \mathrm{D}-\mathrm{H}$ & $45 \mathrm{G}-\mathrm{K}$ & $8 \mathrm{~N}-\mathrm{Q}$ & $0 \mathrm{Q}$ & 0 Q & $0 \mathrm{Q}$ \\
\hline TAM 107, 24 & $100 \mathrm{~A}$ & $93 \mathrm{~A}-\mathrm{C}$ & 87 A-D & $80 \mathrm{~B}-\mathrm{E}$ & 70 C-G & 40 H-M & $17 \mathrm{M}-\mathrm{Q}$ \\
\hline
\end{tabular}

${ }^{\mathrm{z}}$ Percentages for the 1:25 dilution are identical to that of the 1:50 dilution and are not shown. Treatments not having a letter in common are significantly different using the least significance difference test $(P=0.05)$. 
varying levels of susceptibility to WSMV infection were included: Trego, Jagger, 2145, Ike, Karl 92, and 2137. A randomized complete block experimental design was used for each of 3 years, with each treatment replicated four times. Plots (healthy or infected for each cultivar) con-

sisted of three rows, $2.9 \mathrm{~m}$ long with a 0.3 $\mathrm{m}$ row spacing, seeded at $50 \mathrm{~kg} / \mathrm{ha}$. Planting was done on 22 September 2000, 12 September 2002, and 25 September 2003. Plants were inoculated with the Sidney 81 isolate at the two-to-three leaf stage (13 October 2000, 26 September 2002, and 21

Table 4. Days to first symptom expression (FSE), symptom severity, and dry weight, of CO960293 wheat mechanically inoculated with different Wheat streak mosaic virus (WSMV) isolates and held at $24^{\circ} \mathrm{C}$ for 3 weeks $^{\mathrm{w}}$

\begin{tabular}{|c|c|c|c|}
\hline Virus isolate or control & FSE $^{\mathbf{x}}$ & Symptom severity & Dry weight $(\mathbf{m g})^{\mathrm{z}}$ \\
\hline Uninoculated control 1 & $15.0 \mathrm{~A}$ & $1.0 \mathrm{D}$ & $594 \mathrm{AB}$ \\
\hline Uninoculated control 2 & $15.0 \mathrm{~A}$ & $1.0 \mathrm{D}$ & $643 \mathrm{AB}$ \\
\hline Uninoculated control 3 & $15.0 \mathrm{~A}$ & $1.0 \mathrm{D}$ & $659 \mathrm{AB}$ \\
\hline El Batán 3 & $15.0 \mathrm{~A}$ & $1.0 \mathrm{D}$ & $642 \mathrm{AB}$ \\
\hline WO93 & $11.2 \mathrm{~B}$ & $2.2 \mathrm{CD}$ & $688 \mathrm{~A}$ \\
\hline CO87 & $9.7 \mathrm{BC}$ & $2.2 \mathrm{CD}$ & $611 \mathrm{AB}$ \\
\hline PV106 & $9.2 \mathrm{BCD}$ & $2.2 \mathrm{CD}$ & $582 \mathrm{AB}$ \\
\hline KY00 & $9.0 \mathrm{BCD}$ & $2.5 \mathrm{BCD}$ & $663 \mathrm{AB}$ \\
\hline RO95 & 8.5 BCD & $3.5 \mathrm{ABC}$ & $479 \mathrm{AB}$ \\
\hline $\mathrm{IHC}$ & 8.5 BCD & $3.0 \mathrm{ABC}$ & $530 \mathrm{AB}$ \\
\hline OSU & 8.5 BCD & $2.7 \mathrm{BC}$ & $550 \mathrm{AB}$ \\
\hline GO93 & $8.2 \mathrm{BCD}$ & $3.0 \mathrm{ABC}$ & $525 \mathrm{AB}$ \\
\hline H95LB & $8.0 \mathrm{CD}$ & $2.7 \mathrm{BC}$ & $616 \mathrm{AB}$ \\
\hline $\mathrm{H} 88$ & $8.0 \mathrm{CD}$ & $3.0 \mathrm{ABC}$ & $574 \mathrm{AB}$ \\
\hline PV57 & $8.0 \mathrm{CD}$ & $2.7 \mathrm{BC}$ & $577 \mathrm{AB}$ \\
\hline ID96 & $8.0 \mathrm{CD}$ & $2.5 \mathrm{BCD}$ & $591 \mathrm{AB}$ \\
\hline Sidney 81 & $7.7 \mathrm{CD}$ & $3.0 \mathrm{ABC}$ & $625 \mathrm{AB}$ \\
\hline TK1 & $7.7 \mathrm{CD}$ & $3.0 \mathrm{ABC}$ & $469 \mathrm{AB}$ \\
\hline ID99 & $7.7 \mathrm{CD}$ & $3.0 \mathrm{ABC}$ & $606 \mathrm{AB}$ \\
\hline TX96 & $7.7 \mathrm{CD}$ & $3.2 \mathrm{ABC}$ & $519 \mathrm{AB}$ \\
\hline MON96 & $7.7 \mathrm{CD}$ & $3.7 \mathrm{ABC}$ & $515 \mathrm{AB}$ \\
\hline WA99 & $7.7 \mathrm{CD}$ & $3.5 \mathrm{ABC}$ & $525 \mathrm{AB}$ \\
\hline ND & $7.7 \mathrm{CD}$ & $3.5 \mathrm{ABC}$ & $450 \mathrm{AB}$ \\
\hline PV91 & $7.5 \mathrm{CD}$ & $3.2 \mathrm{ABC}$ & $575 \mathrm{AB}$ \\
\hline CK93 & $7.5 \mathrm{CD}$ & $3.0 \mathrm{ABC}$ & $560 \mathrm{AB}$ \\
\hline MO00 & $7.2 \mathrm{CD}$ & $3.5 \mathrm{ABC}$ & $511 \mathrm{AB}$ \\
\hline BT95 & $7.2 \mathrm{CD}$ & $3.2 \mathrm{ABC}$ & $580 \mathrm{AB}$ \\
\hline CL93 & $7.2 \mathrm{CD}$ & $3.7 \mathrm{ABC}$ & $573 \mathrm{AB}$ \\
\hline HV91 & $7.2 \mathrm{CD}$ & $3.5 \mathrm{ABC}$ & $495 \mathrm{AB}$ \\
\hline GH95 & $7.2 \mathrm{CD}$ & $3.0 \mathrm{ABC}$ & $523 \mathrm{AB}$ \\
\hline SD96 & $7.2 \mathrm{CD}$ & $3.5 \mathrm{ABC}$ & $503 \mathrm{AB}$ \\
\hline EW95 & $7.2 \mathrm{CD}$ & $3.5 \mathrm{ABC}$ & $623 \mathrm{AB}$ \\
\hline GY93 & $7.2 \mathrm{CD}$ & $3.5 \mathrm{ABC}$ & $504 \mathrm{AB}$ \\
\hline H98 & $7.0 \mathrm{CD}$ & $3.0 \mathrm{ABC}$ & $568 \mathrm{AB}$ \\
\hline H81 & $7.0 \mathrm{CD}$ & $2.7 \mathrm{BC}$ & $591 \mathrm{AB}$ \\
\hline KY0083SV & $7.0 \mathrm{CD}$ & $2.7 \mathrm{BC}$ & $629 \mathrm{AB}$ \\
\hline PN95 & $7.0 \mathrm{CD}$ & $3.5 \mathrm{ABC}$ & $480 \mathrm{AB}$ \\
\hline LG92 & $7.0 \mathrm{CD}$ & $4.5 \mathrm{~A}$ & $549 \mathrm{AB}$ \\
\hline PV106JM & $7.0 \mathrm{CD}$ & $3.5 \mathrm{ABC}$ & $548 \mathrm{AB}$ \\
\hline H95S & $6.7 \mathrm{CD}$ & $3.5 \mathrm{ABC}$ & $497 \mathrm{AB}$ \\
\hline КМ93 & $6.7 \mathrm{CD}$ & $3.2 \mathrm{ABC}$ & $575 \mathrm{AB}$ \\
\hline OK98 & $6.7 \mathrm{CD}$ & $3.2 \mathrm{ABC}$ & $611 \mathrm{AB}$ \\
\hline TK2 & $6.7 \mathrm{CD}$ & $3.0 \mathrm{ABC}$ & $570 \mathrm{AB}$ \\
\hline CM93 & $6.7 \mathrm{CD}$ & $4.0 \mathrm{AB}$ & $419 \mathrm{~B}$ \\
\hline H94PM & $6.7 \mathrm{CD}$ & $3.5 \mathrm{ABC}$ & $530 \mathrm{AB}$ \\
\hline HM93 & $6.7 \mathrm{CD}$ & $3.7 \mathrm{ABC}$ & $552 \mathrm{AB}$ \\
\hline FO93 & $6.7 \mathrm{CD}$ & $3.7 \mathrm{ABC}$ & $558 \mathrm{AB}$ \\
\hline PL95 & $6.7 \mathrm{CD}$ & $3.2 \mathrm{ABC}$ & $566 \mathrm{AB}$ \\
\hline LC95 & $6.7 \mathrm{CD}$ & $3.0 \mathrm{ABC}$ & $546 \mathrm{AB}$ \\
\hline NE96 & $6.5 \mathrm{D}$ & $3.0 \mathrm{ABC}$ & $562 \mathrm{AB}$ \\
\hline H94USDA & $6.5 \mathrm{D}$ & $3.2 \mathrm{ABC}$ & $515 \mathrm{AB}$ \\
\hline $\mathrm{H} 94 \mathrm{~S}$ & $6.5 \mathrm{D}$ & $3.5 \mathrm{ABC}$ & $524 \mathrm{AB}$ \\
\hline $\mathrm{CO} 85$ & $6.5 \mathrm{D}$ & $3.2 \mathrm{ABC}$ & $537 \mathrm{AB}$ \\
\hline MO99 & $6.5 \mathrm{D}$ & $3.2 \mathrm{ABC}$ & $561 \mathrm{AB}$ \\
\hline
\end{tabular}

${ }^{\text {w}}$ Treatments not having a letter in common are significantly different using the Tukey's Studentized Range test $(P=0.05)$.

${ }^{\mathrm{x}}$ FSE values represent average days post inoculation for appearance of first symptoms for a given treatment averaged over the three experiments.

${ }^{\mathrm{y}}$ Symptom severity ratings: $1=$ no symptoms, $2=$ faint mosaic, $3=$ moderate mosaic, $4=$ severe mosaic, and $5=$ severe mosaic with yellowing of leaves. The ratings were based on the top three leaves collectively of all plants in a row for each treatment for each experiment.

${ }^{\mathrm{z}}$ Dry weight values represent average value from three experiments. The dry weight of all plants in a row for a given treatment was combined in each experiment.
October 2003) using an air-blast inoculation technique (7). Harvest dates were 17 June 2000, 19 June 2002, and 28 June 2003. The ANOVA was conducted using SAS and significant treatment effects were determined using the LSD test at $P=0.05$.

\section{RESULTS}

WSMV testing of wheat lines. Plants of all wheat lines except CO960293 and KS96HW10-3 developed mosaic symptoms when held at $18^{\circ} \mathrm{C}$ (Table 2). All lines tested at $24^{\circ} \mathrm{C}$ developed mosaic symptoms, including CO960293 and KS96HW10-3. Symptomatic tissue was positive in ELISA, and the symptomless tissue of CO960293 wheat and the KS96HW10-3 control held at $18^{\circ} \mathrm{C}$ all were negative in ELISA (data not shown).

WSMV infectivity assay of CO960293 and parental wheat lines. The parent lines of CO960293 (CO850034, PI 222668, and TAM 107), all became symptomatic and the tissue was infective for plants grown at both 18 and $24^{\circ} \mathrm{C}$ (Table $3)$. At $18^{\circ} \mathrm{C}$, only CO960293 was not infective to Tomahawk wheat plants, although it was infective to Tomahawk assay plants when held at $24^{\circ} \mathrm{C}$. TAM 107 , held at $18^{\circ} \mathrm{C}$, was infective only to the $1: 400$ dilution. At the 1:800 dilution, significant differences in percentages of infected Tomahawk wheat plants were observed between the 18 and $24^{\circ} \mathrm{C}$ treatments for each wheat line. We also tested wheat lines of similar origin to PI222668 (PI22651 to PI222682) and these also developed symptoms at $18^{\circ} \mathrm{C}$ (Table 2).

Wsml gene probe. The chromosome 4A substitution line CI15092 and the chromosome 4-DL translocation line KS96HW10-3 contained the identical 241bp SCAR marker (data not shown). By contrast, no SCAR band was detected in PCR amplifications of DNA extracts of CO960293, CO960315, CO960255, TAM 107 , or the spring wheat cvs. AC Elsa or AC Superb.

Temperature and WSMV isolate interactions on $\mathrm{CO960293}$ resistance. At $18^{\circ} \mathrm{C}$, none of the 51 WSMV isolates caused symptom expression in CO960293, nor did they cause any significant reduction in dry weight when compared with healthy controls (data not shown). However, at $24^{\circ} \mathrm{C}$, all WSMV isolates except $\mathrm{El}$ Batán 3 induced symptoms (Table 4). First-symptom expression on CO960293 varied from 6.7 to 11.2 days and was significantly different for some isolates. All uninoculated controls and plants inoculated with the El Batán 3 isolate were symptomless; however, they were assigned a 15-day value to facilitate data analysis. Symptom severity varied among isolates and ranged from 2.2 to 4.5. The WO93 and the CM93 WSMV isolates were significantly different from each other for dry weight, whereas the other isolates were not different. 
Confirmation of infectivity of selected WSMV isolates on $\mathrm{CO960293}$ grown at 18 and $24^{\circ} \mathrm{C}$. At $24^{\circ} \mathrm{C}$, all WSMV isolates caused symptoms in Tomahawk wheat and extracts from these plants were infective to all Tomahawk wheat assay plants in all three experiments. However, at $24^{\circ} \mathrm{C}$, all isolates except El Batán 3 caused symptoms in CO960293 and extracts from the symptomatic leaves were infective to Tomahawk assay plants. In contrast, extracts prepared from the symptomless leaves of CO960293 wheat inoculated with the El Batán 3 isolate were not infective to Tomahawk wheat. At $18^{\circ} \mathrm{C}$, none of the CO960293 wheat plants inoculated with the six WSMV isolates developed symptoms, nor were extracts from these plants infective to Tomahawk wheat. In contrast, all WSMV isolates except El Batán 3 caused symptoms to develop in Tomahawk wheat held at $18^{\circ} \mathrm{C}$ and extracts from the symptomatic Tomahawk wheat was infective to all Tomahawk assay plants in all experiments. Extracts from the symptomless Tomahawk wheat inoculated with the El Batán 3 isolate held at $18^{\circ} \mathrm{C}$ were not infective to Tomahawk wheat.

Yield trials. In both 2000 and 2003, the grain yield and volume weight of entries inoculated with the Sidney 81 isolate of WSMV were not significantly different from healthy controls for both CO960293 and KS96H W10-3 (Table 5). For all other wheat lines, grain yield and volume weight of the inoculated treatment was significantly lower than its healthy control, except for the volume weight of Jagger in 2003. In 2002, all infected treatments except KS96HW10-3 were significantly lower in yield than their healthy controls.

\section{DISCUSSION}

Wheat line CO960293 was grown in the field and was infested naturally by WCM viruliferous for WSMV (8). In this setting, it was observed that none of the plants of this line were symptomatic, whereas all plants (CO960255 and CO960315) in rows growing adjacent to it on either side were symptomatic. When plants grown from seed from these CO960293 plants were tested in replicated experiments mechanically inoculated with WSMV at 18 and $24^{\circ} \mathrm{C}$, only the plants arising from seed of the symptomless CO96293 plants were symptomless at $18^{\circ} \mathrm{C}$ (Table 2). This confirmed that the symptomless plants in the field were not escapes and that CO960293 had temperature-sensitive resistance to WSMV as observed for KS96HW10-3 (13).

CO960293 was selected from the cross PI222668/TAM 107//CO850034. Thus, our assumption was that one of these lines was the source of the resistance seen in the CO960293 plants. When we tested these at 18 and $24^{\circ} \mathrm{C}$, we found that all parents developed symptoms and were highly infective in back assay at $18^{\circ} \mathrm{C}$. The observation that TAM 107 was infected was not unexpected because this wheat line has been demonstrated to be susceptible to mechanical inoculation by WSMV (13). TAM 107 was resistant to WCM infestation $(10,19)$, but we have demonstrated that this resistance is not effective against new biotypes of WCM (4). No information is available in the literature about either CO850034 or PI22668 being resistant to WSMV. Because many PI sources are heterogeneous, it is possible that the WSMV resistance in CO960293 originated from a rare plant within PI22668 that was used in the original cross. We have evaluated many plants from several different samples of PI222668 and have failed to identify any plants with WSMV resistance. We have observed that the resistance from crosses with CO960293 has been recovered easily, although no extensive data are available concerning genetic control of the temperature sensitive resistance derived from CO960293.

Temperature-sensitive WSMV resistance has been identified in KS96HW10-3 wheat (13). Because this line was grown in both breeding nurseries and greenhouses in both Colorado and Kansas, we explored the possibility that an outcross might have occurred and that CO960293 carries the resistance from $A$. intermedium (13). However, when tissue from CO960293 was tested for the presence of J15 (SCAR) DNA marker, no SCAR band was detected in PCR amplifications of DNA extracts of this line, CO960315, CO960255, TAM 107 , or the spring wheat cvs. AC Elsa and AC Superb. By contrast, the chromosome 4A substitution line CI15092 and the chromosome 4-DL translocation line KS96HW10-3 (13) contained the identical 341-bp SCAR marker shown to be tightly linked to the Wsml gene on chromatin derived from A. intermedium chromosome 4 (17). These observations suggest that CO960293 does not carry the resistance from A. intermedium.

When CO960293 was tested against 51 different WSMV isolates at $18^{\circ} \mathrm{C}$, no plants developed symptoms, nor were any differences in dry weight noted among virus treatments at this temperature. Thus, the resistance present at $18^{\circ} \mathrm{C}$ was effective regardless of WSMV isolate source. However, at $24^{\circ} \mathrm{C}$, all isolates except El Batán 3 incited symptoms. The El Batán 3 WSMV isolate was isolated in Mexico (9) and has a coat protein nucleic acid sequence that varies from the Sidney 81 isolate of WSMV by $20 \%$ (16). Such variation may be involved in the apparent lack of systemic infection of CO960293 we observed at $24^{\circ} \mathrm{C}$.

In infectivity assays, we showed that the extracts prepared from symptomless plants of CO960293 inoculated by the El Batán 3 isolate and held at either 18 or $24^{\circ} \mathrm{C}$ were

Table 5. Grain yield and volume weight of wheat cultivars either healthy $(\mathrm{H})$ or infected (I) by Wheat streak mosaic virus over 3 years at Hays, KS

\begin{tabular}{|c|c|c|c|c|c|c|c|}
\hline \multirow[b]{2}{*}{ Cultivar $^{\mathrm{z}}$} & \multirow[b]{2}{*}{ Treatment } & \multicolumn{3}{|c|}{ Yield $(\mathrm{kg} / \mathrm{ha})$ in year } & \multicolumn{3}{|c|}{ Volume $\left(\mathrm{kg} / \mathrm{m}^{3}\right)$ in year } \\
\hline & & 2000 & 2002 & 2003 & 2000 & 2002 & 2003 \\
\hline CO960293 & $\mathrm{H}$ & 4,044 & 3,138 & 4,791 & 755 & 699 & 753 \\
\hline CO960293 & I & 4,172 & $2,392^{*}$ & 4,576 & 750 & 688 & 742 \\
\hline KS96HW10-3 & $\mathrm{H}$ & 4,051 & 2,573 & 3,769 & 795 & 754 & 790 \\
\hline KS96HW10-3 & $\mathrm{I}$ & 4,072 & 2,580 & 3,581 & 798 & 750 & 784 \\
\hline Trego & $\mathrm{H}$ & 4,240 & 3,984 & 5,711 & 800 & 754 & 804 \\
\hline Trego & I & $3,285^{*}$ & $2,761^{*}$ & $3,312^{*}$ & $742 *$ & $715^{*}$ & $696 *$ \\
\hline Jagger & $\mathrm{H}$ & 3,036 & 2,633 & 5,597 & 772 & 712 & 775 \\
\hline Jagger & I & $2,452 *$ & $1,236^{*}$ & $3,574^{*}$ & $709 *$ & $661 *$ & 665 \\
\hline 2145 & $\mathrm{H}$ & 3,072 & 2,714 & 5,415 & 780 & 723 & 795 \\
\hline 2145 & I & $2,035^{*}$ & $490 *$ & $1,841^{*}$ & $708 *$ & $668 *$ & $631 *$ \\
\hline Ike & $\mathrm{H}$ & 3,547 & 2,909 & 5,308 & 777 & 712 & 790 \\
\hline Ike & I & $2,465^{*}$ & $430 *$ & $2,997 *$ & $703 *$ & $654 *$ & $741 *$ \\
\hline Karl 92 & $\mathrm{H}$ & 3,487 & 2,250 & 5,006 & 784 & 721 & 800 \\
\hline Karl 92 & I & $2,606^{*}$ & $1,713^{*}$ & $2,385^{*}$ & $723^{*}$ & $695^{*}$ & $669 *$ \\
\hline 2137 & $\mathrm{H}$ & 3,561 & 2,520 & 4,891 & 771 & 692 & 785 \\
\hline 2137 & I & $2,885^{*}$ & $1,145^{*}$ & $3,003 *$ & $712 *$ & $651 *$ & $694 *$ \\
\hline $\mathrm{CV}^{\mathrm{z}}$ & $\ldots$ & 9.7 & 14.5 & 9.7 & 2.0 & 1.7 & 2.0 \\
\hline LSD (0.05) & $\ldots$ & 571 & 443 & 571 & 22 & 17 & 22 \\
\hline
\end{tabular}

y Asterisk $(*)$ indicates that this value is significantly different from the healthy control for a given wheat line.

${ }^{\mathrm{z}} \mathrm{CV}=$ coefficient of variation and LSD $=$ least significant difference. 
not infective. However, Tomahawk wheat developed symptoms inoculated with this isolate when held at $24^{\circ} \mathrm{C}$ and such tissue was infective to assay plants. This indicated that the inoculum was infective and that the lack of symptoms and infectivity in CO960293 at both temperatures was not because of poor-quality inoculum. The lack of symptoms and infectivity observed for CO960293 wheat at both temperatures and Tomahawk wheat at $18^{\circ} \mathrm{C}$ inoculated with this isolate may reflect the large difference in coat protein nucleic acid sequence observed for this isolate compared with others (16).

Only in fall 2001 were symptoms observed in the CO960293 plots following inoculation (Table 5). The significant reduction in yield of CO960293 in 2002 probably relates to the high temperatures in the week following inoculation that year. The average daily maximum temperature for the week following inoculation was $18.5^{\circ} \mathrm{C}$ for $2000,31^{\circ} \mathrm{C}$ for 2002 , and $18.8^{\circ} \mathrm{C}$ for 2003 . This heat-induced breakdown in resistance in CO960293, but not in KS96HW10-3 during 2002, also supports our Wsml gene analysis, where we could not demonstrate the presence of the J15 SCAR marker in CO960293. Although KS96HW10-3 resistance to WSMV is temperature sensitive (13), this wheat line did not suffer any yield losses in any year due to WSMV infection. This supports the hypothesis that the resistance in $\mathrm{CO} 960293$ is different than that of KS96HW10-3, and that KS96HW10-3 must require slightly higher temperatures of longer duration to induce loss of resistance. The exact temperature conditions (duration of high versus low temperatures) under field conditions at which the resistance is lost has not been determined. Although we demonstrated that the temperature-sensitive resistance was effective in 2 of 3 years for preventing losses to WSMV infection, the use of such resistance probably would be ineffective for growers who use wheat with the dual purpose of grazing and grain production because such wheat usually is planted early, when temperatures are sufficiently high to prevent effective use of the temperature-sensitive resistance should viruliferous WCMs infest the early planted wheat.

In summary, we demonstrated that the temperature-sensitive resistance present in CO960293 was effective in field tests in 2 of 3 years. The temperature-sensitive resistance of this line was demonstrated to be effective at $18^{\circ} \mathrm{C}$ when inoculated by 51 WSMV isolates collected over time and representing a large geographic area. We also proved that the parental lines of CO960293 are susceptible to WSMV infection at both 18 and $24^{\circ} \mathrm{C}$. This indicates that the source of the temperature-sensitive resistance in CO960293 is unknown, but its nature should be elucidated. However, regardless of the source, our data demonstrate that this wheat line can be a valuable source of resistance to WSMV, particularly in areas where temperatures are cool following planting in the fall.

\section{ACKNOWLEDGMENTS}

We thank J. Ackerman for his valuable assistance in conducting the many different experiments during this study, C. Seaman for his assistance in field plantings and harvesting, and J. Higgins and L. Taylor for data analysis.

\section{LITERATURE CITED}

1. Clark, M. F., and Adams, A. N. 1977. Characteristics of the microplate method of enzymelinked immunosorbent assay for the detection of plant viruses. J. Gen. Virol. 34:475-483.

2. Haber, S., Rymerson, R. T., Procunier, J. D., Murray, G., and Cvitkovitch, S. E. 1995. Diagnosis of flame chlorosis by reverse transcription-polymerase reaction (RT-PCR). Plant Dis. 79:626-630.

3. Haley, S. D., Martin, T. J., Quick, J. S., Seifers, D. L., Stromberger, J. A., Clayshulte, S. R. Clifford, B. L., Peairs, F. B., Rudolph, J. B. Johnson, J. J., Gill, B. S., and Friebe, B. 2002. Registration of CO960293-2 wheat germplasm resistant to Wheat streak mosaic virus and Russian wheat aphid. Crop Sci. 42:1381-1382.

4. Harvey, T. L., Seifers, D. L., Martin, T. J., Brown-Guedira, G., and Gill, B. S. 1999. Survival of wheat curl mites on different sources of resistance in wheat. Crop Sci. 38:18871889.

5. Lengkeck, V. H. 1979. Wheat Virus Disease in Southwestern Kansas. Coop. Ext. Rep. Kansas State University, Manhattan.
6. Little, T. M., and Hills, F. J. Hills 1978. Transformation. Pages 139-165 in: Agricultural Experimentation: Design and Analysis. T. M. Little and F. J. Hills, eds. John Wiley and Sons, Inc., New York.

7. Martin, T. J., and Hackerott, H. L. 1982 Greenhouse seedling technique to determine the reaction of sorghum to maize dwarf mosaic virus strain A. Crop Sci. 22:1255-1256.

8. Martin, T. J., and Harvey, T. L. 1992. Field screening procedure for resistance to wheat streak mosaic virus. Cereal Res. Commun. 20:213-215.

9. Sánchez-Sánchez, H., Henry, M., CárdenasSoriano, E., and Alviso-Villasana, H. F. 2001 Identification of Wheat streak mosaic virus and its vector Aceria tosichella in Mexico. Plant Dis. 85:13-17.

10. Sebesta, E. E., Wood, E. A., Jr., Porter, D. R., Webster, J. A., and Smith, E. L. 1994. Registration of gaucho Greenbug-resistant triticale germplasm. Crop Sci. 34:1428.

11. Seifers, D. L. 1992. Partial characterization of a Colorado isolate of Agropyron mosaic virus. Plant Dis. 76:564-569.

12. Seifers, D. L., and Martin, T. J. 1988. Correlation of low level of Wheat streak mosaic virus resistance in Triumph 64 wheat with low virus titer. Phytopathology 78:703-707.

13. Seifers, D. L., Martin, T. J., Harvey, T. L., and Gill, B. S. 1995. Temperature sensitivity and efficacy of wheat streak mosaic virus resistance derived from Agropyron intermedium. Plant Dis. 79:1104-1106.

14. Sim, T., IV, Willis, W. G., and Eversmeyer, M. G. 1988. Kansas plant disease survey. Plant Dis. $72: 832-836$.

15. Slykuis, J. T. 1955. Aceria tulipae Keifer (Acarina: Eriophyidae) in relation to the spread of wheat streak mosaic. Phytopathology 45:116-128.

16. Stenger, D. C., Seifers, D. L., and French, R. 2002. Patterns of polymorphism in Wheat streak mosaic virus: sequence space explored by a clade of closely related viral genotypes rivals that between the most divergent strains. Virology 302:58-70.

17. Talbert, L. E., Bruckner, P. L., Smith, L. Y., Sears, R., and Martin, T. J. 1996. Development of PCR markers linked to resistance to Wheat streak mosaic virus in wheat. Theor. Appl. Genet. 93:463-467.

18. Willis, W. G. 1981. The 1981 Wheat Streak Mosaic Epidemic in Kansas. Coop. Ext. Rep. Kansas State University, Manhattan.

19. Wood, E. A., Jr., Sebesta, E. E., Webster, J. A. and Porter, D. R. 1995. Resistance to wheat curl mite (Acari:Eriophyidae) in Greenbugresistant 'Gaucho' triticale and 'Gaucho' $\times$ wheat crosses. J. Econ. Entomol. 88:10321036. 